\title{
Use of Azadirachta indica (AZI) as green corrosion inhibitor against mild steel in acidic medium: anti-corrosive efficacy and adsorptive behaviour
}

\author{
A. Peter and S.K. Sharma* \\ Green Chemistry and Sustainability Research Group, Department of Chemistry, \\ JECRC University, Jaipur-303905, India \\ *E-mail:sk.sharmaa@outlook.com
}

\begin{abstract}
The corrosion inhibition of mild steel in $1 \mathrm{~N} \mathrm{HCl}, \mathrm{H}_{2} \mathrm{SO}_{4}$ and $\mathrm{HNO}_{3}$ solution in the presence of AZI at a temperature of $304 \& 313 \mathrm{~K}$ was studied using weight loss techniques. The Neem (AZI) works as an inhibitor in the acid surroundings. The results showed that the inhibition efficiency was increased by increasing the inhibitor concentration and reached the maximum at $1000 \mathrm{ppm}(72 \mathrm{hr})$ in $1 \mathrm{~N} \mathrm{HCl}$ and $\mathrm{H}_{2} \mathrm{SO}_{4}$ and in $\mathrm{HNO}_{3}$ solution. The AZI was found to follow Langmuir adsorption isotherm at all the concentrations in different acidic mediums studied. The phenomenon of physical adsorption obtained and the process is spontaneous.
\end{abstract}

Keywords: mild steel, adsorption, corrosion, inhibitor, green chemistry.

Received: January 18, 2017. Published: March 21, 2017.

doi: $\underline{10.17675 / 2305-6894-2017-6-2-2}$

\section{Introduction}

Mild steel is applicable in industrial and structural applications on a large level. Acid solutions are consistently used in a number of operations in for scrubbing, scraping and storing of steel structure; developments which are calculated as the extensive termination of the metal and it is mandatory to add corrosion inhibitors to govern the corrosion rate for the advancement of surroundings. Most of the Organic heterogeneous compounds holding these elements have been reported to be proficient corrosion inhibitors [1-8]. The corrodent attack can be controlled by an adsorption mechanism with the presence of heteroatom and aromatic rings. A number of authors have been inventing the use of plant parts or extracts as corrosion inhibitor [9-19]. They are readily available, cost effective, non-toxic, biodegradable in nature which drives the attention to work on them as a corrosion inhibitor. Wide list of literature we have found the nurturing use of natural plant origin to inhibit the corrosion of different metals in different mediums (Acid \& alkaline) [20-25]. Authors of this paper have published a comprehensive review [26] focusing the potential of Azadirachta indica as a green corrosion inhibitor against mild steel, aluminum, and tin, which inspired the authors to carry out the present study. The present study is 
designed to investigate the adsorption and inhibiting properties of water extract of leaves of Azadirachta indica for the corrosion of mild steel in $1 \mathrm{~N} \mathrm{HCl}, \mathrm{H}_{2} \mathrm{SO}_{4}$ and $\mathrm{HNO}_{3}$ solutions.

Azadirachta indica consists its place in the mahogany family of Meliaceae. Neem rich countries are India, Bangladesh, Thailand, Nepal, and Pakistan. "Tree of the 21st century (Neem)" is well known for its medicinal uses in human day to day life. In India, there are many names for this tree like "Heavenly Tree", "Lifetime enhancing tree", "Environment's Dispensary", "Community Apothecary" [27-30]. The chemical constituents found in the leaves of neem as Nimbin, nimbanene, 6-desacetylnimbinene, nimban-diol, nimbolide, ascorbic acid, n-hexacosanol and aminoacid, 7-desacetyl-7-benzoylazadiradione, 7desacetyl-7-benzoylgedbenzoylgedunin, 17-hydroxyazadiradione and nimbiol [31-33].

\section{Materials and methods}

\subsection{Materials}

The mild steel sheets $(98.9 \%)$ were cut into $3 \times 2 \times 0.2 \mathrm{~cm}$ dimension to form specific metal coupons. Each coupon was scratched by emery paper in order to obtain a smooth surface, washed with water to make it free from dust and rinsed with acetone to make it dry, for the preservation of treated coupons we transferred them into the desiccator. All components and chemicals used for the experimental work were anlar grade and distilled water was used for their preparation.

\subsection{Solutions}

Leaves of Azadirachta indica were collected from the Sanganer region in Jaipur (Rajasthan). The Leaves were washed and dried, crushed and held in reserve in glass jars till use. Standard solutions of the leaves were equipped by soaking $50 \mathrm{~g}$ of the dehydrated and crushed leaves in $1000 \mathrm{ml}$ of, particularly distilled water. The resulted solution was maintained for 24 hours, filtered and stored. From the stock solution $(0.05 \mathrm{~g} / 1)$, we equipped different concentrations [250, 500, 750, $1000 \mathrm{ppm}(\mathrm{mg} / \mathrm{ml})]$ solutions [34]. The $1 \mathrm{~N} \mathrm{HCl}$ solution was equipped by dilution of analytical grade $\mathrm{HCl}, \mathrm{H}_{2} \mathrm{SO}_{4}$ and $\mathrm{HNO}_{3}$ solutions with distilled water and all trials were passed out in unstirred solutions.

\subsection{Weight Loss Method}

Weight loss parameters were functioning on the mild steel samples with a four-sided form of size $3 \times 2 \times 0.2 \mathrm{~cm}$ in one normal $\mathrm{HCl}, \mathrm{H}_{2} \mathrm{SO}_{4}$ and $\mathrm{HNO}_{3}$ solution with and without the addition of different concentrations $(250,500,750,1000 \mathrm{ppm})$ of neem leaves extract. Each sample was evaluated in SHIMADZU (ATX224) electronic balance and then sited in the acid solution $(100 \mathrm{ml})$. The period of the involvement was $6,24,48,72 \mathrm{~h}$ at the temperature range $304 \& 313 \mathrm{~K}$. Afterward, involvement, the surface of the MS metal coupon was washed with double distilled water and carry on the drying with acetone and the sample was considered one more time weighed in order to calculate inhibition efficiency $(E \%)$ and the corrosion rate $(C R)$. Every testing followed by freshly equipped 
solution and the solution temperature was thermostatically prescribed at a preferred assessment.

The surface coverage $(\theta)$ and inhibition efficiency $\left(E^{\%}\right)$ was determined by using the following equation

$$
\begin{gathered}
\theta=w_{0}-w_{i} / w_{0} \\
E^{\mathrm{o}}=\left(w_{0}-w_{i} / w_{0}\right) \times 100
\end{gathered}
$$

Where $w_{i}$ and $w_{0}$ are the weight loss values in the presence and absence of inhibitor, respectively. The corrosion rate $(C R)$ of mild steel was calculated using the following relation:

$$
C R=\frac{\text { weight loss }}{\text { area } \times \text { time } \times \text { density }} \times 8.76 \times 10^{4}
$$

Where $w$ is corrosion weight loss of mild steel $(\mathrm{g})$, area of the coupon $\left(\mathrm{cm}^{2}\right), t(\mathrm{~h})$, and density of mild steel in $\left(\mathrm{g} \mathrm{cm}^{-3}\right)$.

\subsection{GC-MS Study}

GC-MS investigation was run away with a GC Clarus 500 Perkin Elmer system embracing an AOC-20i auto sampler and gas chromatograph interfaced to a mass spectrometer (GCMS) apparatus.

\subsection{Surface Analysis}

External appearance studies of the mild steel surface were commenced by SEM inspection using Nova Nano SEM 450 BRUKER Scanning electron microscope from Malaviya National institute of technology, (MNIT) Jaipur.

\section{Results and discussion}

Figures 1, 2, 3 indicate the variety of weight loss, IE\% and corrosion proportion with the time for the corrosion of mild steel in a solution of [A] $1 \mathrm{~N} \mathrm{HCl},[B] \mathrm{H}_{2} \mathrm{SO}_{4}$, [C] $\mathrm{HNO}_{3}$ holding prescribed concentrations of AZI (Neem) at 304 and $313 \mathrm{~K}$. We resolved from the figures that the weight loss of mild steel surges with the increasing duration of contact, but it's caught control with a surge in the concentration of Azardirachta indica. Corrosion rates upsurge with an upsurge in temperature. Resulted observations pointed that AZI effective to condense the mild steel corrosion in all three acidic media $\left(1 \mathrm{~N} \mathrm{HCl} \mathrm{H}_{2} \mathrm{SO}_{4} \& \mathrm{HNO}_{3}\right)$, but the highest weight loss stated in $\mathrm{HNO}_{3}$ medium due to $\mathrm{HNO}_{3}$ acids hyper oxidative behave [35], however, we have seen the inhibition in $\mathrm{HNO}_{3}$ medium very low, so we can say that inhibitor is more effective in the other acid medium as compare to $\mathrm{HNO}_{3}$ solution. Consequently, the Tables 1 and 2 show the relative data of standard metal loss, corrosion rate and inhibition efficiency of the corroded samples of mild steel at 304 and $313 \mathrm{~K}$. The maximum efficiency of mild steel $(70.2 \%)$ has been observed in the highest inhibitor 
concentration $1000 \mathrm{ppm}$ at $72 \mathrm{hr}$ at a temperature of $304 \mathrm{~K}$ in $1 \mathrm{~N} \mathrm{HCL}, 65.6 \%$ for $72 \mathrm{hr}$ on $1000 \mathrm{ppm}$ in $1 \mathrm{~N} \mathrm{H}_{2} \mathrm{SO}_{4}$ and $52.6 \%$ for $72 \mathrm{hr}$ on $1000 \mathrm{ppm}$ in $1 \mathrm{~N} \mathrm{HNO}_{3}$ medium.
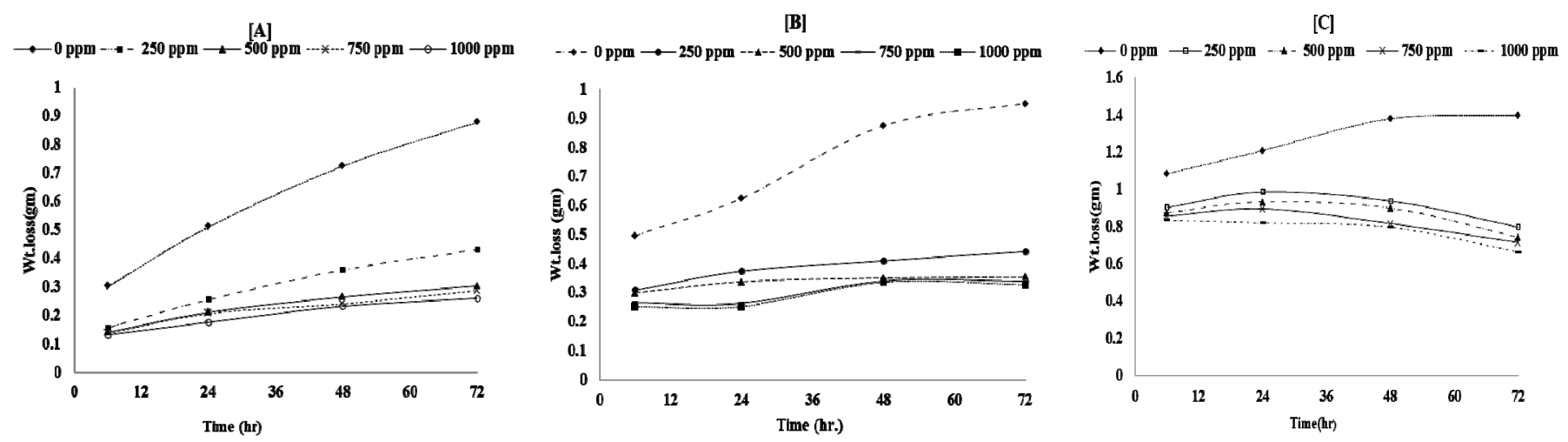

Figure 1. Weight loss graphs of mild steel with different concentration of AZI in [A] $1 \mathrm{~N} \mathrm{HCl,}$ [B] $1 \mathrm{~N} \mathrm{H}_{2} \mathrm{SO}_{4}$ and [C] $1 \mathrm{~N} \mathrm{HNO}_{3}$.
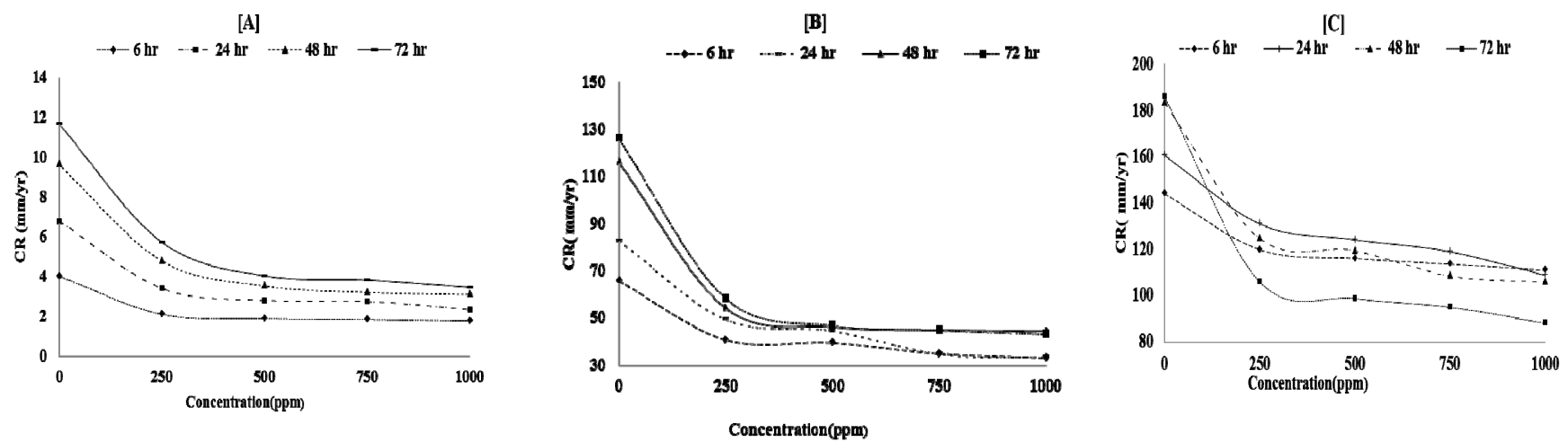

Figure 2. Corrosion rate graphs of $\mathrm{MS}$ with different concentration of $\mathrm{AZI}$ in [A] $1 \mathrm{~N} \mathrm{HCl}$, [B] $1 \mathrm{~N} \mathrm{H}_{2} \mathrm{SO}_{4}$ and [C] $1 \mathrm{~N} \mathrm{HNO}_{3}$.
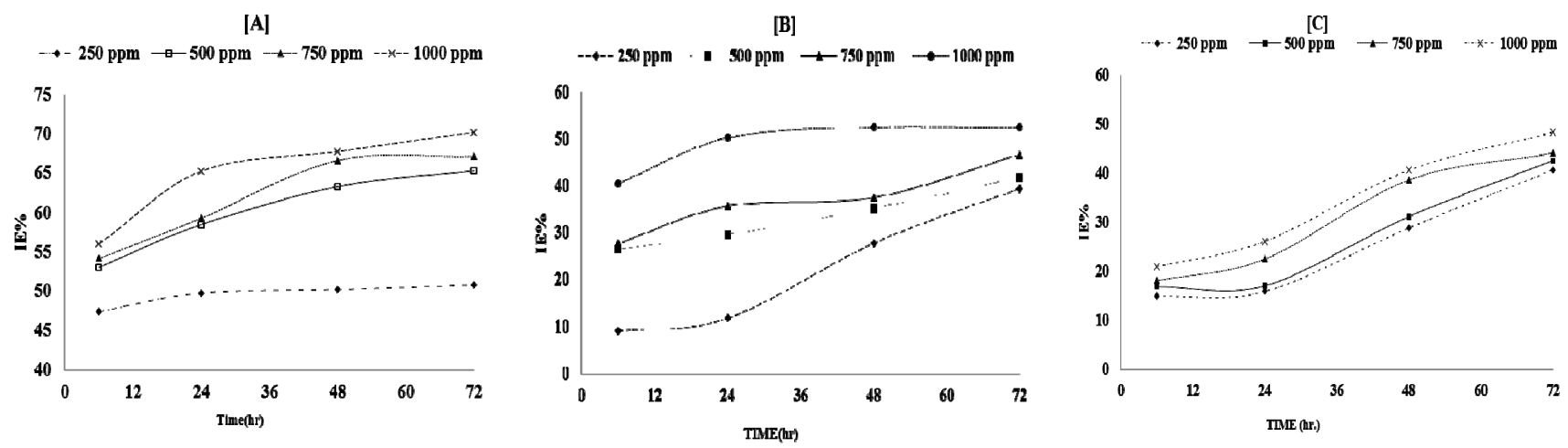

Figure 3. Inhibition efficiency graphs of MS with different concentration of AZI in [A] $1 \mathrm{~N}$ $\mathrm{HCl}$, [B] $1 \mathrm{~N} \mathrm{H}_{2} \mathrm{SO}_{4}$ and [C] $1 \mathrm{~N} \mathrm{HNO}_{3}$. 
Table 1. Corrosion parameters of AZI at $304 \mathrm{~K}$ in different acidic medium with mild steel at different immersion time periods.

\begin{tabular}{|c|c|c|c|c|c|c|c|c|c|c|c|c|c|}
\hline \multirow[b]{2}{*}{ Medium } & \multirow{2}{*}{$\begin{array}{c}\text { Inhibitor } \\
\text { conc. }\end{array}$} & \multicolumn{3}{|c|}{$6 \mathrm{hr}$} & \multicolumn{3}{|c|}{$24 \mathrm{hr}$} & \multicolumn{3}{|c|}{$48 \mathrm{hr}$} & \multicolumn{3}{|c|}{$72 \mathrm{hr}$} \\
\hline & & $\begin{array}{l}\text { Wt. } \\
\text { loss } \\
\text { (gm) }\end{array}$ & $\begin{array}{c}C R, \\
\mathrm{~mm} / \mathrm{yr}\end{array}$ & IE\% & $\begin{array}{l}\text { Wt. } \\
\text { loss } \\
\text { (gm) }\end{array}$ & $\begin{array}{c}C R, \\
\mathrm{~mm} / \mathrm{yr}\end{array}$ & IE\% & $\begin{array}{l}\text { Wt. } \\
\text { loss } \\
\text { (gm) }\end{array}$ & $\begin{array}{c}C R, \\
\mathrm{~mm} / \mathrm{yr}\end{array}$ & IE\% & $\begin{array}{l}\text { Wt. } \\
\text { loss } \\
\text { (gm) }\end{array}$ & $\begin{array}{c}C R, \\
\mathrm{~mm} / \mathrm{yr}\end{array}$ & IE\% \\
\hline \multirow{5}{*}{$\begin{array}{l}1 \mathrm{~N} \\
\mathrm{HCl}\end{array}$} & 0 & 0.308 & 4.0977 & & 0.512 & 6.806 & & 0.726 & 9.6403 & & 0.879 & 11.68 & \\
\hline & 250 & 0.159 & 2.1156 & 48.37 & 0.257 & 3.420 & 49.74 & 0.361 & 4.8009 & 50.19 & 0.433 & 5.747 & 50.8 \\
\hline & 500 & 0.142 & 1.8902 & 53.87 & 0.213 & 2.823 & 58.52 & 0.266 & 3.5392 & 63.28 & 0.305 & 4.052 & 65.3 \\
\hline & 750 & 0.139 & 1.8453 & 54.97 & 0.208 & 2.768 & 59.33 & 0.242 & 3.2186 & 66.61 & 0.289 & 3.834 & 67.1 \\
\hline & 1000 & 0.133 & 1.7696 & 56.81 & 0.178 & 2.365 & 65.25 & 0.234 & 3.1056 & 67.78 & 0.262 & 3.478 & 70.2 \\
\hline \multirow{5}{*}{$\begin{array}{c}1 \mathrm{~N} \\
\mathrm{H}_{2} \mathrm{SO}_{4}\end{array}$} & 0 & 0.496 & 65.949 & & 0.625 & 83.005 & & 0.875 & 116.29 & & 0.951 & 126.32 & \\
\hline & 250 & 0.309 & 41.006 & 37.82 & 0.373 & 49.57 & 40.27 & 0.410 & 54.433 & 53.19 & 0.441 & 58.57 & 53.6 \\
\hline & 500 & 0.299 & 39.733 & 39.75 & 0.338 & 44.864 & 45.95 & 0.350 & 46.487 & 60.02 & 0.353 & 46.95 & 62.8 \\
\hline & 750 & 0.264 & 35.065 & 46.83 & 0.263 & 34.926 & 57.92 & 0.340 & 45.197 & 61.13 & 0.340 & 45.106 & 64.3 \\
\hline & 1000 & 0.252 & 33.455 & 49.27 & 0.253 & 33.562 & 59.56 & 0.336 & 44.692 & 61.56 & 0.327 & 43.50 & 65.6 \\
\hline \multirow{5}{*}{$\begin{array}{c}1 \mathrm{~N} \\
\mathrm{HNO}_{3}\end{array}$} & 0 & 1.084 & 144.01 & & 1.210 & 160.68 & & 1.380 & 183.38 & & 1.400 & 185.9 & \\
\hline & 250 & 0.902 & 119.88 & 16.75 & 0.986 & 131.01 & 18.46 & 0.938 & 124.62 & 32.23 & 0.797 & 105.95 & 43 \\
\hline & 500 & 0.874 & 116.14 & 19.35 & 0.934 & 124.10 & 22.76 & 0.899 & 119.49 & 34.84 & 0.743 & 98.76 & 46.9 \\
\hline & 750 & 0.856 & 113.66 & 21.07 & 0.896 & 119.02 & 25.92 & 0.817 & 108.5 & 40.83 & 0.715 & 94.97 & 48.9 \\
\hline & 1000 & 0.834 & 110.85 & 23.02 & 0.819 & 108.84 & 32.25 & 0.797 & 105.89 & 42.25 & 0.664 & 88.21 & 52.6 \\
\hline
\end{tabular}

Table 2. Corrosion parameters of AZI at $313 \mathrm{~K}$ temperature in different acidic medium with mild steel at different immersion time periods.

\begin{tabular}{|c|c|c|c|c|c|c|c|c|c|c|c|c|c|}
\hline \multirow[b]{2}{*}{ Medium } & \multirow[b]{2}{*}{$\begin{array}{l}\text { Inhibitor } \\
\text { conc. }\end{array}$} & \multicolumn{3}{|c|}{$6 \mathrm{hr}$} & \multicolumn{3}{|c|}{$24 \mathrm{hr}$} & \multicolumn{3}{|c|}{$48 \mathrm{hr}$} & \multicolumn{3}{|c|}{$72 \mathrm{hr}$} \\
\hline & & $\begin{array}{l}\text { Wt. } \\
\text { loss } \\
\text { (gm) }\end{array}$ & $\begin{array}{c}C R \\
\mathrm{~mm} / \mathrm{yr}\end{array}$ & IE\% & $\begin{array}{l}\text { Wt. } \\
\text { loss } \\
\text { (gm) }\end{array}$ & $\begin{array}{c}C R \\
\mathrm{~mm} / \mathbf{y r}\end{array}$ & IE\% & $\begin{array}{l}\text { Wt. } \\
\text { loss } \\
\text { (gm) }\end{array}$ & $\begin{array}{c}C R \\
\mathrm{~mm} / \mathrm{yr}\end{array}$ & IE\% & $\begin{array}{l}\text { Wt. } \\
\text { loss } \\
\text { (gm) }\end{array}$ & $\begin{array}{c}C R \\
\mathrm{~mm} / \mathrm{yr}\end{array}$ & IE $\%$ \\
\hline \multirow{4}{*}{$\begin{array}{l}1 \mathrm{~N} \\
\mathrm{HCl}\end{array}$} & 0 & 0.400 & 5.314 & & 0.596 & 7.917 & & 0.726 & 9.644 & & 0.880 & 11.688 & \\
\hline & 250 & 0.228 & 3.023 & 43.10 & 0.318 & 4.230 & 46.56 & 0.365 & 4.847 & 49.73 & 0.433 & 5.749 & 50.808 \\
\hline & 750 & 0.199 & 2.642 & 50.27 & 0.261 & 3.460 & 56.28 & 0.287 & 3.818 & 60.40 & 0.318 & 4.229 & 63.815 \\
\hline & 1000 & 0.165 & 2.1964 & 58.67 & 0.243 & 3.221 & 59.30 & 0.270 & 3.589 & 62.78 & 0.297 & 3.950 & 66.21 \\
\hline \multirow{2}{*}{$\begin{array}{c}1 \mathrm{~N} \\
\mathrm{H}_{2} \mathrm{SO}_{4}\end{array}$} & 0 & 0.571 & 75.803 & & 0.722 & 95.94 & & 0.970 & 128.88 & & 1.066 & 141.60 & \\
\hline & 250 & 0.387 & 51.390 & 32.20 & 0.462 & 61.40 & 35.99 & 0.517 & 68.72 & 46.68 & 0.540 & 71.68 & 49.374 \\
\hline \multirow{5}{*}{$\begin{array}{c}1 \mathrm{~N} \\
\mathrm{HNO}_{3}\end{array}$} & 0 & 1.140 & 151.47 & & 1.242 & 164.96 & & 1.448 & 192.35 & & 1.522 & 202.25 & \\
\hline & 250 & 0.969 & 128.76 & 14.99 & 1.044 & 138.68 & 15.93 & 1.029 & 136.75 & 28.90 & 0.903 & 119.95 & 40.693 \\
\hline & 500 & 0.947 & 125.82 & 16.93 & 1.030 & 136.78 & 17.08 & 0.996 & 132.35 & 31.19 & 0.874 & 116.11 & 42.59 \\
\hline & 750 & 0.933 & 123.96 & 18.16 & 0.962 & 127.77 & 22.54 & 0.888 & 117.98 & 38.66 & 0.851 & 113.04 & 44.111 \\
\hline & 1000 & 0.900 & 119.61 & 21.03 & 0.917 & 121.79 & 26.17 & 0.859 & 114.17 & 40.64 & 0.786 & 104.44 & 48.36 \\
\hline
\end{tabular}




\subsection{Kinetic studies}

Mainly corrosion reactions are first order signifying that it follows a mode [35]

$$
-\log (\text { weight loss })=k_{1} t / 2.303
$$

Where $t$ is the period of contact and $k_{1}$ is the first order rate constant. Figures 4,5 and Table 3 shows values and plots for the variation of $-\log$ (weight loss) with time for the corrosion of MS in the deficiency and the existence of AZI different concentrations at 304 and $313 \mathrm{~K}$ on different intervals $(6,24,48$ and $72 \mathrm{hrs})$. Received the straight line plots with good $R^{2}$ values confirm that Azardirachta indica as a good inhibitor for mild steel in different acidic mediums.

Table 3. Kinetic parameters for the corrosion of mild steel in $1 \mathrm{~N} \mathrm{HCl}, \mathrm{H}_{2} \mathrm{SO}_{4} \& \mathrm{HNO}_{3}$ containing various concentrations of AZI.

\begin{tabular}{|c|c|c|c|c|c|c|c|c|c|c|c|c|}
\hline \multicolumn{13}{|c|}{$304 \mathrm{~K}$} \\
\hline & $\begin{array}{l}\text { Conc. } \\
\text { (ppm) }\end{array}$ & $B$ & $K$ & $R^{2}$ & & $B$ & $K$ & $R^{2}$ & & $B$ & $K$ & $R^{2}$ \\
\hline \multirow{5}{*}{$\begin{array}{l}1 \mathrm{~N} \\
\mathrm{HCl}\end{array}$} & 0 & -0.151 & 0.62 & 0.96 & \multirow{5}{*}{$\begin{array}{c}1 \mathrm{~N} \\
\mathrm{H}_{2} \mathrm{SO}_{4}\end{array}$} & -0.099 & 0.395 & 0.96 & \multirow{5}{*}{$\begin{array}{c}1 \mathrm{~N} \\
\mathrm{HNO}_{3}\end{array}$} & -0.039 & 0.003 & 0.7 \\
\hline & 250 & -0.144 & 0.91 & 0.96 & & -0.05 & 0.546 & 0.95 & & -0.018 & 0.001 & 0.9 \\
\hline & 500 & -0.109 & 0.92 & 0.95 & & -0.023 & 0.534 & 0.832 & & 0.022 & 0.008 & 0.89 \\
\hline & 750 & -0.102 & 0.92 & 0.94 & & -0.044 & 0.634 & 0.79 & & 0.027 & 0.018 & 0.76 \\
\hline & 1000 & -0.099 & 0.95 & 0.97 & & -0.046 & 0.655 & 0.76 & & 0.031 & 0.033 & 0.74 \\
\hline \multicolumn{13}{|c|}{$313 \mathrm{~K}$} \\
\hline & $\begin{array}{l}\text { Conc. } \\
\text { (ppm) }\end{array}$ & $B$ & $K$ & $R^{2}$ & & $B$ & $K$ & $R^{2}$ & & $B$ & $K$ & $R^{2}$ \\
\hline \multirow{5}{*}{$\begin{array}{l}1 \mathrm{~N} \\
\mathrm{HCl}\end{array}$} & 0 & -0.111 & 0.482 & 0.96 & \multirow{5}{*}{$\begin{array}{c}1 \mathrm{~N} \\
\mathrm{H}_{2} \mathrm{SO}_{4}\end{array}$} & -0.094 & 0.328 & 0.96 & \multirow{5}{*}{$\begin{array}{c}1 \mathrm{~N} \\
\mathrm{HNO}_{3}\end{array}$} & -0.044 & 0.012 & 0.97 \\
\hline & 250 & -0.089 & 0.709 & 0.99 & & -0.048 & 0.0446 & 0.947 & & 0.009 & 0.018 & 0.19 \\
\hline & 500 & -0.059 & 0.7 & 0.98 & & -0.044 & 0.455 & 0.88 & & 0.011 & 0.012 & 0.25 \\
\hline & 750 & -0.065 & 0.744 & 0.98 & & -0.024 & 0.469 & 0.55 & & 0.015 & 0.03 & 0.73 \\
\hline & 1000 & -0.081 & 0.826 & 0.99 & & -0.031 & 0.516 & 0.54 & & 0.02 & 0.012 & 0.78 \\
\hline
\end{tabular}




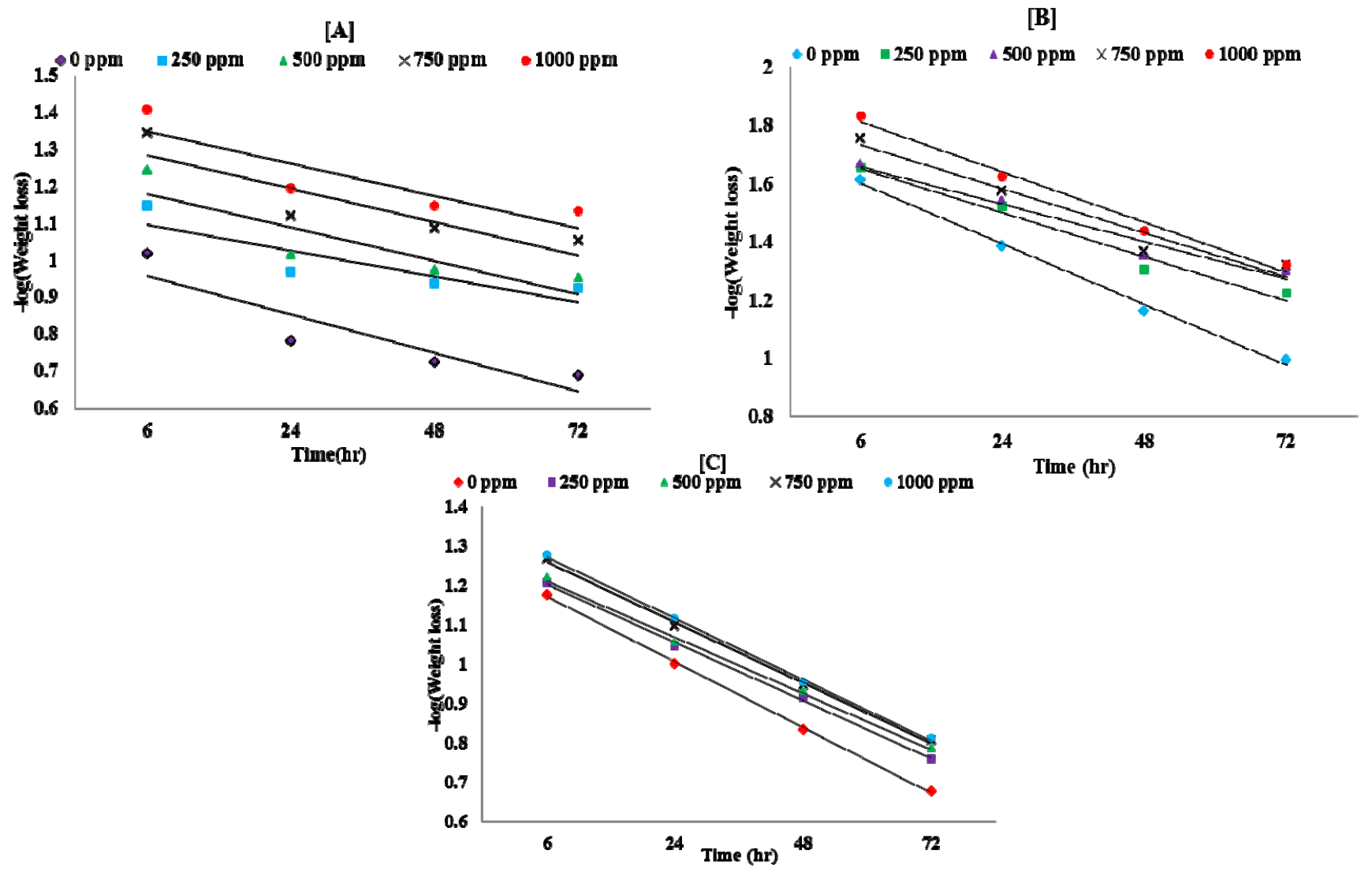

Figure 4. Variation of $-\log$ (weight loss) versus time for the corrosion of mild steel in solutions of $1 \mathrm{~N} \mathrm{HCl}, \mathrm{H}_{2} \mathrm{SO}_{4} \& \mathrm{HNO}_{3}$ containing various concentrations of $\mathrm{AZI}$ at $304 \mathrm{~K}$ temperature.

\section{Effect of temperature}

Activation energies help us to know that surface interaction energy $E_{\mathrm{a}}$ for the corrosion of mild steel in the non-existent and in the existences of AZI have estimated using the logarithmic form of the Arrhenius equation, which can be articulated as follows [36].

$$
E_{\mathrm{a}}=2.303 R \cdot \log \left(\frac{C R_{1}}{C R_{2}}\right) /\left(T_{1}-\frac{T_{2}}{T_{1} \cdot T_{2}}\right)
$$

Where $C R_{1}$ and $C R_{2}$ are the corrosion rates of mild steel at the temperatures $T_{1}(304 \mathrm{~K})$ and $T_{2}(313 \mathrm{~K})$, respectively, $E_{\mathrm{a}}$ is the triggering/activation energy, and $R$ is the gas constant. Activation energy values $\left(E_{\mathrm{a}}\right)$ ranged from 0.04 to $37.66 \mathrm{~kJ} / \mathrm{mol}$ for mild steel in $1 \mathrm{~N} \mathrm{HCl}$ medium, 9.04 to $32.1 \mathrm{~kJ} / \mathrm{mol}$ for $\mathrm{MS}$ in $\mathrm{H}_{2} \mathrm{SO}_{4}, 2.3$ to $15.3 \mathrm{~kJ} / \mathrm{mol}$ in $\mathrm{HNO}_{3}$ medium with different concentrations of inhibitor the $E_{\mathrm{a}}$ values are comparably less than $40 \mathrm{~kJ} / \mathrm{mol}$. On the whole, minor values of $E_{\mathrm{a}}$ point to an affinity towards physisorption phenomena. Obtained result in Table 4 authorizes that the adsorption of AZI on the surface of MS in $1 \mathrm{~N} \mathrm{HCl}, \mathrm{H}_{2} \mathrm{SO}_{4} \& \mathrm{HNO}_{3}$ medium monitors the physisorption. 


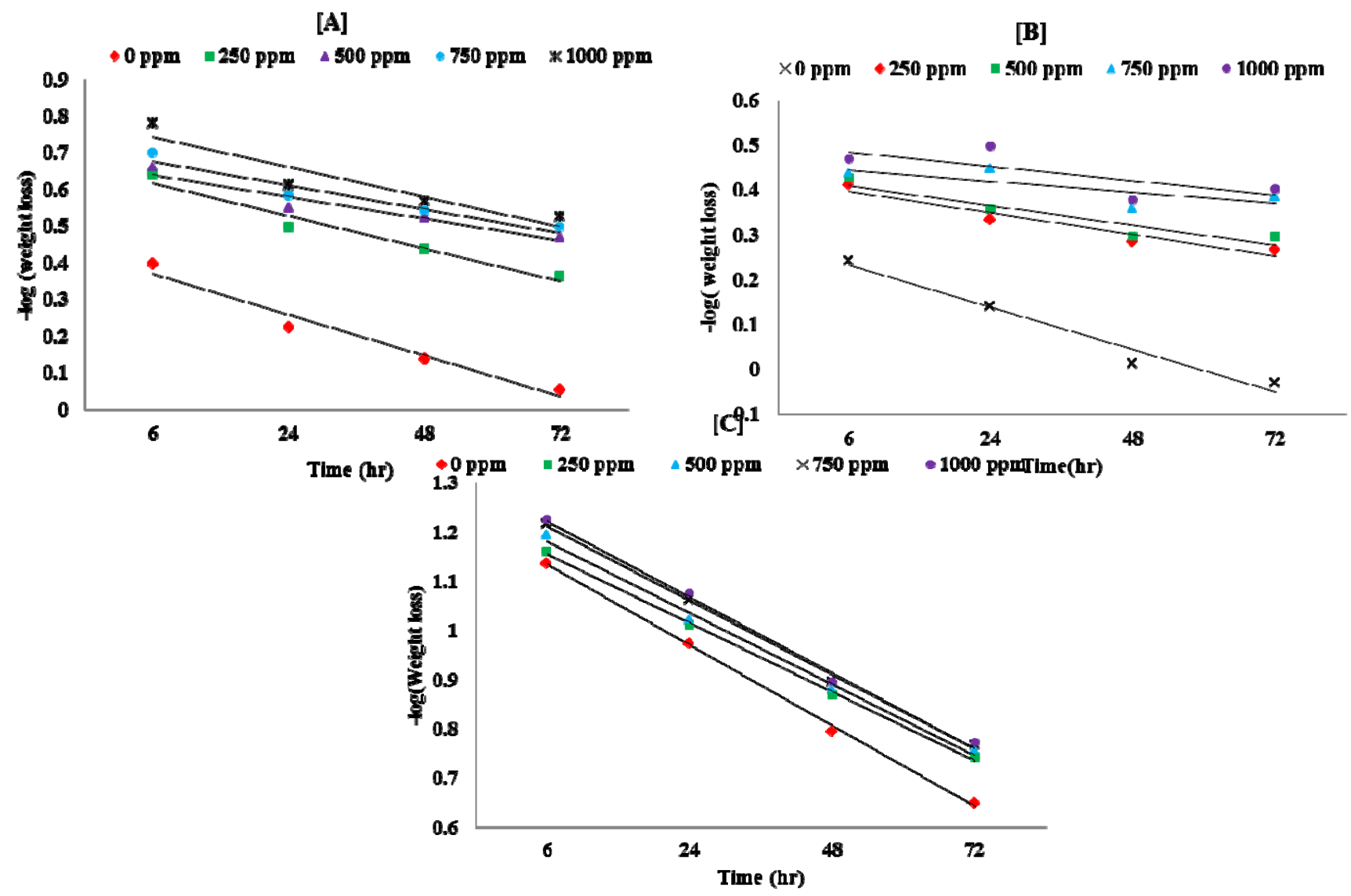

Figure 5. Variation of - $\log$ (weight loss) versus time for the corrosion of MS in solutions of $1 \mathrm{~N} \mathrm{HCl}, \mathrm{H}_{2} \mathrm{SO}_{4} \& \mathrm{HNO}_{3}$ containing various concentrations of AZI at $313 \mathrm{~K}$ temperature.

Table 4. Calculated values of apparent activation energy (Ea) and Heat of adsorption (Q) of AZI on mild steel in $1 \mathrm{~N} \mathrm{HCl}, \mathrm{H}_{2} \mathrm{SO}_{4}$ and $\mathrm{HNO}_{3}$ medium.

\begin{tabular}{|c|c|c|c|c|c|c|c|c|c|}
\hline \multirow{2}{*}{$\begin{array}{c}\text { AZI } \\
\text { Concentration } \\
(\text { ppm })\end{array}$} & \multirow{2}{*}{ Medium } & \multicolumn{4}{|c|}{$E_{\mathrm{a}}\left(\mathrm{kJ} \mathrm{mol}^{-1}\right)$} & \multicolumn{4}{|c|}{$Q_{\text {ads }}\left(\mathrm{kJ} \mathrm{mol}^{-1}\right)$} \\
\hline & & $6 \mathrm{hr}$ & $24 h r$ & $48 \mathrm{hr}$ & $72 \mathrm{hr}$ & $6 \mathrm{hr}$ & $24 h r$ & $48 \mathrm{hr}$ & $72 \mathrm{hr}$ \\
\hline 0 & & 22.86 & 13.28 & 0.04 & 0.04 & & & & \\
\hline 250 & & 31.4 & 18.67 & 0.857 & 0.04 & -2.14 & -2.12 & -2.05 & -2.06 \\
\hline 500 & $1 \mathrm{~N} \mathrm{HCl}$ & 37.66 & 24.44 & 10 & 8.909 & -2.53 & -2.75 & -3.17 & -3.39 \\
\hline 750 & & 31.58 & 19.63 & 15.03 & 8.496 & -2.46 & -2.73 & -3.67 & -3.64 \\
\hline 1000 & & 18.98 & 27.17 & 12.72 & 11.19 & -2.35 & -3.47 & -3.8 & -4.18 \\
\hline 0 & & 12.24 & 12.74 & 9.04 & 10.03 & & & & \\
\hline 250 & $1 \mathrm{~N} \mathrm{H}_{2} \mathrm{SO}_{4}$ & 19.85 & 18.81 & 20.49 & 17.76 & -1.89 & -1.87 & -2.42 & -2.36 \\
\hline 500 & & 19.92 & 23.24 & 32.1 & 31.23 & -1.91 & -2.11 & -3.11 & -3.33 \\
\hline
\end{tabular}




\begin{tabular}{cccccccccc}
\hline 750 & & & & & & & & \\
\hline 1000 & $1 \mathrm{~N} \mathrm{H}_{2} \mathrm{SO}_{4}$ & 28.41 & 26.57 & 22.01 & 16.7 & -2.29 & -2.76 & -3.01 & -3.23 \\
\hline 0 & & 26.25 & 20.07 & 19.17 & 16.57 & -2.3 & -2.77 & -3 & -3.39 \\
\hline 250 & & 4.447 & 2.313 & 4.201 & 7.396 & & & & \\
500 & & 6.287 & 4.999 & 8.165 & 10.93 & -1.93 & -1.92 & -1.75 & -1.86 \\
750 & & & & & & \\
$1 \mathrm{~N} \mathrm{HNO}_{3}$ & & 7.036 & 8.549 & 8.987 & 14.23 & -1.88 & -1.99 & -1.78 & -2.05 \\
1000 & & 7.631 & 6.231 & 7.366 & 15.3 & -1.86 & -1.79 & -1.8 & -2.15 \\
& & 6.687 & 9.876 & 6.624 & 14.84 & -1.77 & -1.88 & -1.81 & -2.3 \\
\hline
\end{tabular}

\section{Thermodynamics and adsorption study}

The heat of adsorption of Azardirachta indica on mild steel surface was calculated using the following equation [37]

$$
Q_{a d s}=2.303 R\left(\log \frac{\theta_{2}}{1-\theta_{2}}-\log \frac{\theta_{1}}{1-\theta_{1}}\right) \times \frac{T_{1} T_{2}}{T_{2}-T_{1}}
$$

Where $R$ is the universal gas constant, $\theta_{2}$ and $\theta_{1}$ are the degree of surface coverage at the temperatures $T_{1}(304 \mathrm{~K})$ and $T_{2}(313 \mathrm{~K})$. In Table 4 we can see the values of $Q_{\text {ads }}$ for prescribed concentrations of AZI. We have found negative values of heat adsorption for all concentrations of AZI inhibitor presenting that the adsorption of Neem on the surface of the mild steel is exothermic. We calculate the surface coverage $(\theta)$ values by using formula number (1).

If the adsorbent (water \& acid) and adsorbate (AZI) are in touch long enough then an equilibrium will be built between the amount of adsorbate in solution and the amount of adsorbate adsorbed. Isotherms made to determine the equilibrium. Communication between the metal surface and inhibitor can be defined by adsorption mechanism. The degree of surface exposure, for the $1 \mathrm{~N} \mathrm{HCl}, \mathrm{H}_{2} \mathrm{SO}_{4}$ and $\mathrm{HNO}_{3}$ mediums with different concentration $(250,500,750 \& 1000 \mathrm{ppm})$ of AZI inhibitor studied was calculated from the weight loss measurements. The surface coverage values for the inhibitor were fitted into the Langmuir adsorption isotherm model.

$$
\frac{C}{\theta}=C+\frac{1}{K_{\mathrm{ads}}}
$$

In the formula, $C$ stands for the concentration of the inhibitor (AZI), $\theta$ is the substantial surface coverage, and $K_{\text {ads }}$ denotes the adsorption equilibrium constant. From the intercepts of the straight line $\mathrm{C}_{\mathrm{inh}} / \theta$ - axis, $K$ value was considered and from the graph, the value originated can be rationalized by theoretical value. As we knew that the adsorbed molecule decreases the surface area which was accessible for the corrosion reactions to occur.

Figure 6 shows the plot of $C / \theta$ against $C$ for [A] $1 \mathrm{~N} \mathrm{HCl,} \mathrm{[B]} 1 \mathrm{~N} \mathrm{H}_{2} \mathrm{SO}_{4}$, [C] $1 \mathrm{~N}$ $\mathrm{HNO}_{3}$ at $304 \mathrm{~K}$ temperature. Linear plots were obtained indicating that the experimental results fit into Langmuir isotherm. $K$ is the equilibrium constant of adsorption process and $C$ is the concentration of AZI. $K$ is related to the free energy of adsorption by the equation: 


$$
\Delta G_{\mathrm{ads}}=-R T \ln \left(K_{\mathrm{ad}} \times 55.5\right)
$$

The plots between $C / \theta$ and concentration of inhibitor at $304 \mathrm{~K} \& 313 \mathrm{~K}$ is shown in Figures $6 \& 7$. From the plot, straight lines obtained for AZI show that its adsorption on the mild steel surface follows Langmuir isotherm. The free energy of adsorption values, $\Delta G_{\text {ads }}$, were obtained from Eqn. (8). The values obtained are presented in Table 5. Results presented in the table indicate that the values of $\Delta G_{\text {ads }}$ are negative in all cases. The negative values also point towards an instantaneous adsorption of the inhibitor molecules which are signs of physical adsorption on the surface of the metal [38].

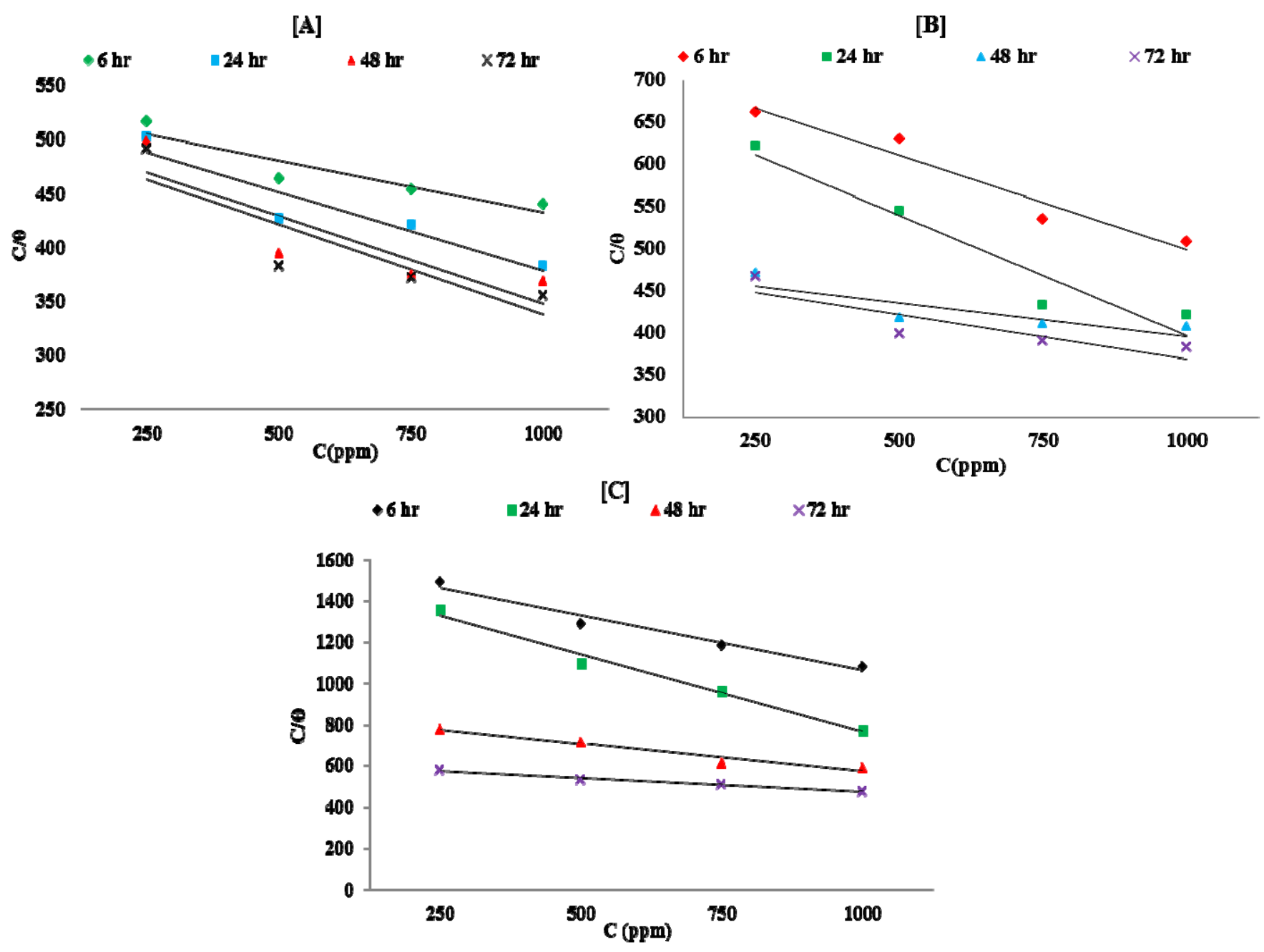

Figure 6. Adsorption isotherms for the AZI on mild steel in different acid medium at $304 \mathrm{~K}$ temperature. [A] Langmuir isotherm in $1 \mathrm{~N} \mathrm{HCl}$, [B] $1 \mathrm{~N} \mathrm{H}_{2} \mathrm{SO}_{4}$ and [C] $1 \mathrm{~N} \mathrm{HNO}_{3}$. 


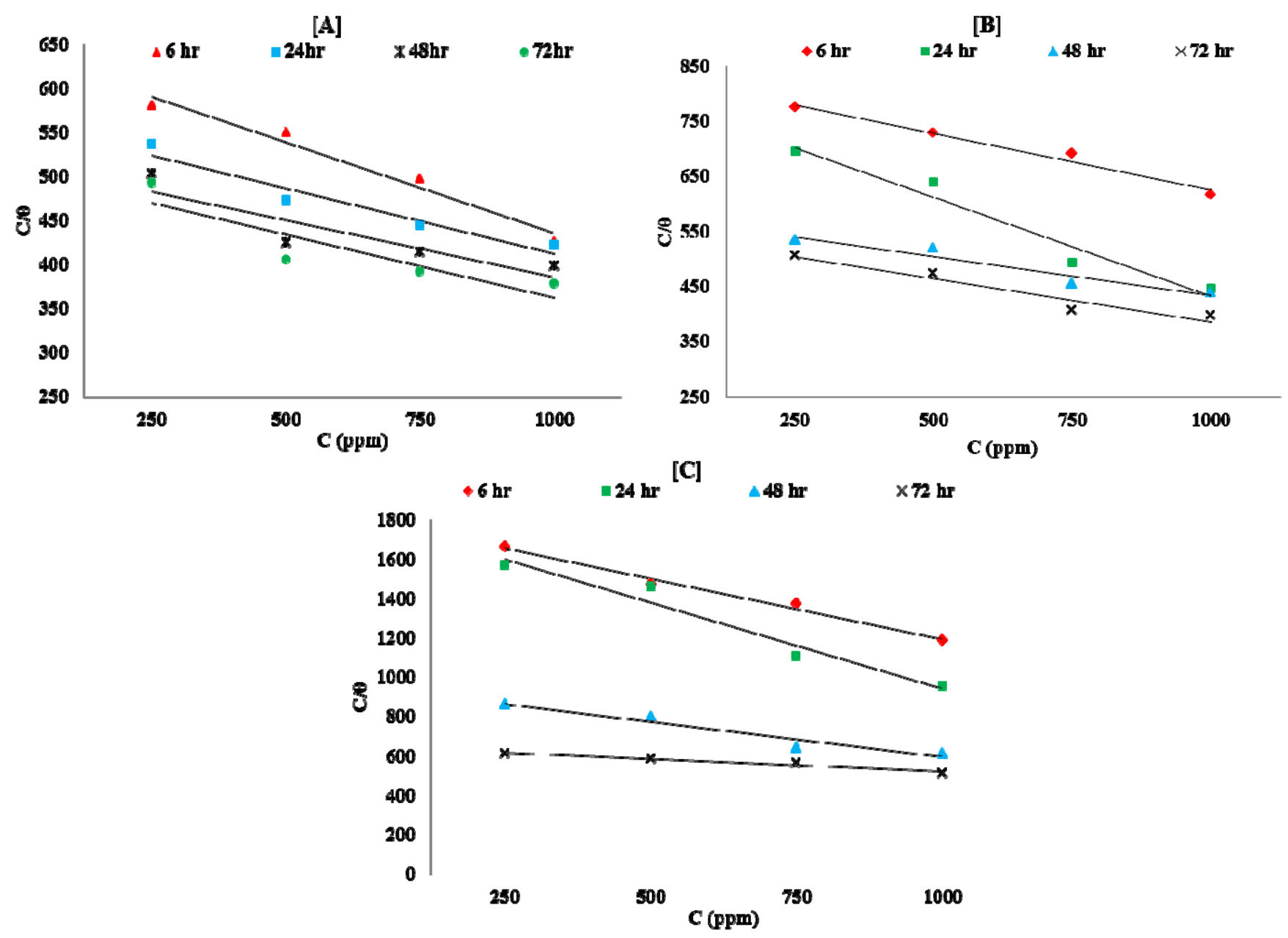

Figure 7. Adsorption isotherms for the AZI on mild steel in different acid medium at $313 \mathrm{~K}$ temperature. [A] Langmuir isotherm in $1 \mathrm{~N} \mathrm{HCl},[\mathrm{B}] 1 \mathrm{~N} \mathrm{H}_{2} \mathrm{SO}_{4}$ and [C] $1 \mathrm{~N} \mathrm{HNO}_{3}$.

Table 5. Parameters for the adsorption of AZI on mild steel surface at $304 \mathrm{~K} \& 313 \mathrm{~K}$ temperature.

\begin{tabular}{|c|c|c|c|c|c|c|c|c|c|c|c|}
\hline \multirow{2}{*}{$\begin{array}{l}\text { Applied } \\
\text { isotherm }\end{array}$} & \multirow[b]{2}{*}{ Medium } & \multirow{2}{*}{$\begin{array}{c}\text { Conc. } \\
\text { ppm }\end{array}$} & \multirow{2}{*}{$\begin{array}{c}\text { Time } \\
\text { (hr) }\end{array}$} & \multicolumn{4}{|c|}{$304 K$} & \multicolumn{4}{|c|}{ 313K } \\
\hline & & & & $\boldsymbol{B}$ & $\underset{\mathbf{p p m}^{-1}}{K_{\mathrm{ads}}}$ & $R^{2}$ & $\begin{array}{c}\Delta G_{\mathrm{ads}} \\
\mathrm{kJ} \mathrm{mol}^{-1}\end{array}$ & B & $\underset{\mathbf{p p m}^{-1}}{K_{\mathrm{ads}}}$ & $R^{2}$ & $\underset{\mathrm{kJ} \mathrm{mol}^{-1}}{\Delta G_{\mathrm{ads}}}$ \\
\hline \multirow{2}{*}{$\begin{array}{l}\text { Langmuir } \\
\text { adsorption } \\
\text { isotherm }\end{array}$} & \multirow{2}{*}{$1 \mathrm{~N} \mathrm{HCl}$} & 250 & 6 & -23.96 & 528.84 & 0.97 & -26.00011 & -51.5 & 642.22 & 0.82 & -26.49106 \\
\hline & & 500 & 24 & -36.4 & 524.58 & 0.98 & -25.97967 & -37.42 & 562.32 & 0.94 & -26.15526 \\
\hline \multirow{4}{*}{$\begin{array}{l}\text { Langmuir } \\
\text { adsorption } \\
\text { isotherm }\end{array}$} & \multirow{4}{*}{$\begin{array}{c}1 \mathrm{~N} \\
\mathrm{H}_{2} \mathrm{SO}_{4}\end{array}$} & 250 & 6 & -55.59 & 721.76 & 0.94 & -26.78617 & -51.49 & 832.68 & 0.97 & -27.14749 \\
\hline & & 500 & 24 & -71.55 & 682.93 & 0.93 & -26.6464 & -89.22 & 791.2 & 0.96 & -27.01834 \\
\hline & & 750 & 48 & -19.93 & 475.2 & 0.74 & -25.7298 & -35.343 & 575.96 & 0.93 & -26.21584 \\
\hline & & 1000 & 72 & -26.35 & 474.43 & 0.76 & -25.7257 & -39.46 & 544.87 & 0.94 & -26.07559 \\
\hline $\begin{array}{l}\text { Langmuir } \\
\text { adsorption } \\
\text { isotherm }\end{array}$ & $\begin{array}{c}1 \mathrm{~N} \\
\mathrm{HNO}_{3}\end{array}$ & 1000 & 72 & -33.8 & 609.75 & 0.98 & -26.35993 & -31.251 & 649.38 & 0.96 & -26.51908 \\
\hline
\end{tabular}




\section{GCMS analysis}

The chromatogram of compounds which were reported in GCMS of Azardiracta indica are following: Phenol, 2-methoxy-4-propyl-; Digitoxin; Cyclohexanol, 4-[(trimethylsilyl)oxy]-, cis-; Hexadecanoic acid, 1,1-dimethylethyl ester; Cyclononasiloxane, octadecamethyl-; Cyclopentanol, 2-cyclopentylidene-; Octadecanoic acid, butyl ester; Cyclononasiloxane, octadecamethyl-; 2,6-Dimethyl-4-nitro-3-phenyl-cyclohexanone; 1,2-Propanediol, 3benzyloxy-1,2-diacetyl-; Heptasiloxane, hexadecamethyl-; 2-(3-Hydroxy-2-nitro-1phenylbutyl)cyclohexane, Succinic acid, 3,7-dimethyloct-6-en-1-yl isobutyl; Butyl myristate; Stearic acid, 3-(octadecyloxy)propyl esters; 1-Penten-3-one, 4,4-dimethyl-1phenyl-; beta-Tocopherol; Retinol, acetate; Andrographolide; trans-Dehydroandrosterone, methyl ether. Clarification on mass spectrum GC-MS was accompanied using the databank of National Institute Standard and Technology (NIST) having more than 62,000 designs. The spectrum of the unfamiliar constituent was paralleled with the spectrum of the known constituent compounds deposited in the NIST library.

From the GC-MS spectrum Of AZI, it is evident that the spectrum of AZI consisted of 33 peaks with various values of retention time (RT) and fragmentation peaks. Because the area below a chromatogram is proportional to the concentration of the analyte, area normalization was carried out in categorize to calculate the percentage constituent of molecules identified in each peak. Long carbon chain or aromatic compounds have reported in GCMS analysis.

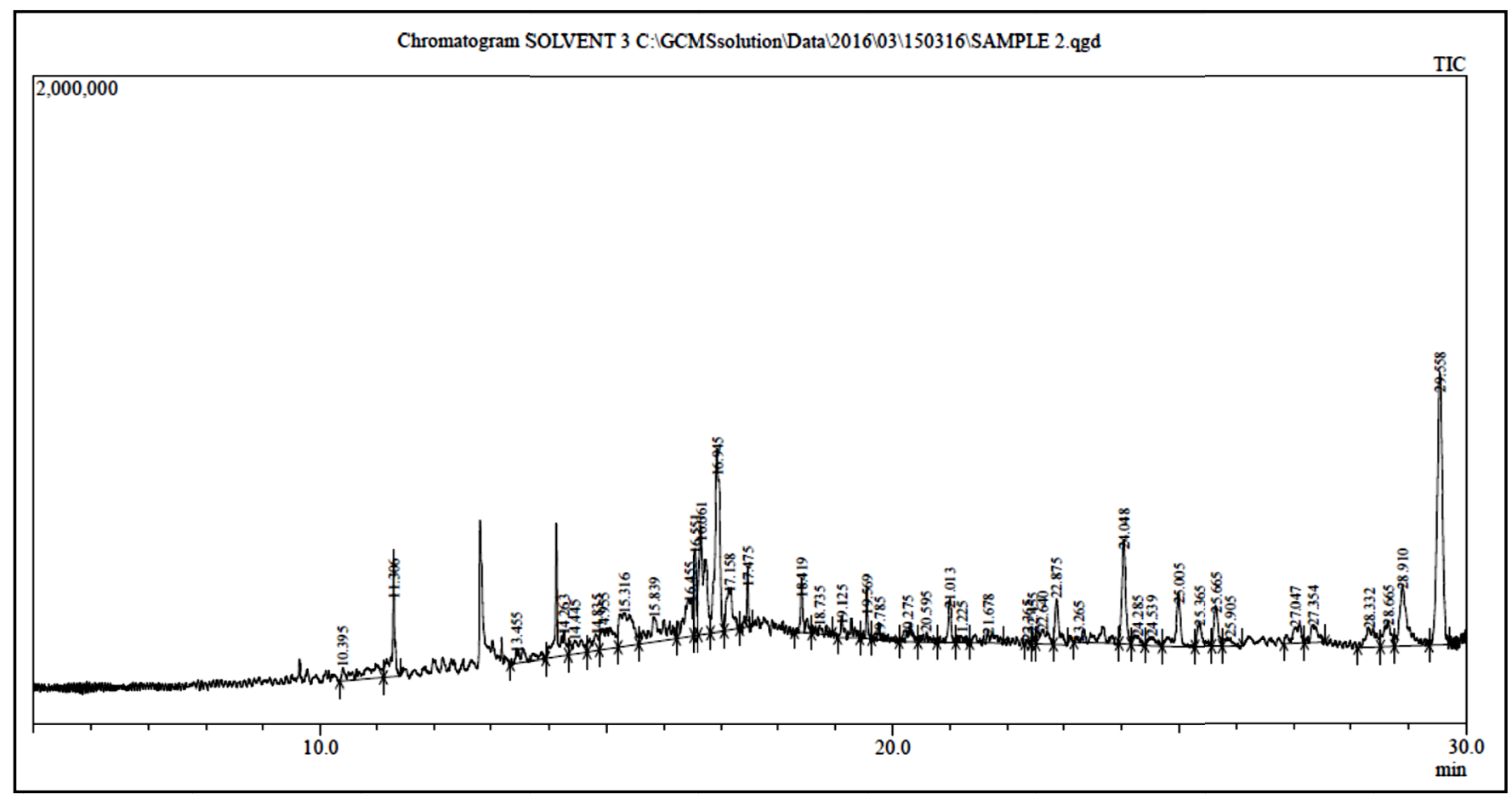

Figure 8. GCMS spectrum of Azardirachta indica. 
In Figure 8 we can understand the relative inhibitory capacity of Neem (AZI) inhibitor for mild steel corrosion in all acidic mediums, we have found that in all three acidic mediums ( $1 \mathrm{~N} \mathrm{HCl}, \mathrm{H}_{2} \mathrm{SO}_{4}$ and $\mathrm{HNO}_{3}$ ) medium inhibitor effectiveness upsurge with increasing concentration but in $1 \mathrm{~N} \mathrm{HNO}_{3}$ we have observed very low inhibition capacity due to hyper oxidative nature. AZI has been initiated to be an active mild steel corrosion inhibitor in $1 \mathrm{~N} \mathrm{HCl}, \mathrm{H}_{2} \mathrm{SO}_{4}$ and $\mathrm{HNO}_{3}$ medium.

\section{Mechanism}

The course of mild steel termination in acidic medium, i.e. $\left(1 \mathrm{~N} \mathrm{HCl}, 1 \mathrm{~N} \mathrm{H}_{2} \mathrm{SO}_{4}\right.$ and $1 \mathrm{~N}$ $\mathrm{HNO}_{3}$ ) relies on concentrations of anions in the solution as observed

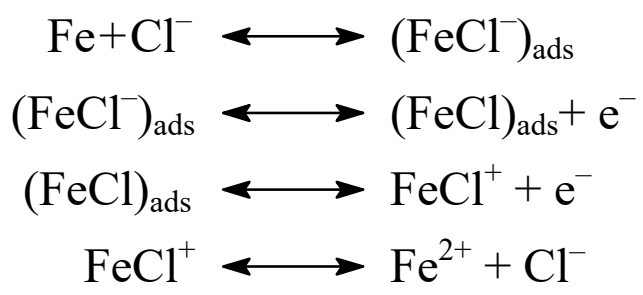

When we add Azardirachta indica (AZI) as an inhibitor to acid solution different additional phases are involved depending on the nature of the electrolyte in the mechanism of anodic dissolution:

$$
\begin{aligned}
\left(\mathrm{FeCl}^{-}\right)_{\mathrm{ads}}+\mathrm{H}^{+} \mathrm{AZI} & \longleftrightarrow\left(\mathrm{FeCl}^{-} \mathrm{H}^{+} \mathrm{AZI}\right)_{\mathrm{ads}} \\
\left(\mathrm{FeCl}^{-} \mathrm{H}^{+} \mathrm{AZI}\right)_{\mathrm{ads}} & \longleftrightarrow\left(\mathrm{FeH}^{+} \mathrm{AZI}\right)_{\mathrm{ads}}+\mathrm{Cl}^{-}
\end{aligned}
$$

In acidic medium reduction mechanism is not affected by the presence of the inhibitor because hydrogen evolution is activated controlled step. Due to this there is retardation in the rate of the cathodic reaction by the inhibitor and the possible pathways of the cathodic reaction are following

$$
\begin{aligned}
\mathrm{Fe}+\mathrm{H}^{+}+\mathrm{e}^{-} & \longleftrightarrow(\mathrm{FeH})_{\mathrm{ads}} \\
\mathrm{Fe}+\left(\mathrm{H}^{+} \mathrm{AZI}\right)+\mathrm{e}^{-} & \longleftrightarrow(\mathrm{FeH} \mathrm{AZI})_{\mathrm{ads}} \\
(\mathrm{FeH})_{\mathrm{ads}}+(\mathrm{FeH})_{\mathrm{ads}} & \longleftrightarrow 2 \mathrm{Fe}+\mathrm{H}_{2}
\end{aligned}
$$

As a conclusion, we can say that there is competition between $\mathrm{H}^{+}$and $\mathrm{H}^{+} \mathrm{AZI}$ (protonated inhibitor) for the similar active site to get adsorbed on the surface. The corrosion rate is greater in the nitric acid medium, followed by sulfuric acid, and last of all hydrochloric acid. The breakdown visibility in nitric acid is very significant because nitric acid is identified to be a strong oxidizing agent [39].

The primary dislocation of $\mathrm{H}^{+}$ions from the solutions is followed by $\mathrm{HNO}_{3}$ reduction relative to the hydrogen evolution since the acid reduction clues to a noticeable drop in free energy.

$$
\mathrm{Fe}+4 \mathrm{HNO}_{3} \longrightarrow \mathrm{Fe}\left(\mathrm{NO}_{3}\right)_{2}+2 \mathrm{H}_{2} \mathrm{O}+2 \mathrm{NO}_{2}
$$


This response clues to the evolution of nitrogen(II) oxide and production of $\mathrm{Fe}\left(\mathrm{NO}_{3}\right)_{2}$ which directed to the furtherance coloration of the medium [40, 41]. We consider the same mechanism of inhibition, which has been presented in our recently published research paper on gums [42].

\section{SEM analysis}

The surface morphology of treated mild steel examined by electron microscope is shown in Figure 9 for samples (MS) treated with $1 \mathrm{~N}$ hydrochloric acid and Figures 10 \& 11 for samples (MS) treated with $1 \mathrm{~N}$ sulfuric acid and $\mathrm{HNO}_{3}$ solution. Each figure shows scanning electron micrographs of the tested surfaces with and without inhibitor. All figures show the surface morphology of mild steel. Scanning electron micrograph of plain mild steel shows analogous grooves with moderately light areas, which were identified as a clean surface. Figure 9 shows the surface morphology of plain mild steel and exposed MS to $1 \mathrm{~N}$ hydrochloric acid without inhibitor or with inhibitor on best potent efficiency $(1000 \mathrm{ppm}$, $72 \mathrm{hr}$ ). Figure 10 shows the surface morphology of plain MS and MS exposed to $1 \mathrm{~N} \mathrm{H}_{2} \mathrm{SO}_{4}$ in the without inhibitor or with inhibitor on best potent efficiency (1000 ppm, $72 \mathrm{hr}$ ) and in Figure 11 we obtained the surface morphology of plain MS and MS exposed to $1 \mathrm{~N} \mathrm{HNO}_{3}$ without inhibitor or with inhibitor on best potent efficiency (1000 ppm, $72 \mathrm{hr}$ ). In every figure, we can clearly found the more fine surface images which were treated with an inhibitor (AZI) as compared to without inhibitor. In Figure 12 we have plotted the comparative graph analysis of MS corrosion in all three acidic medium hours wisely.
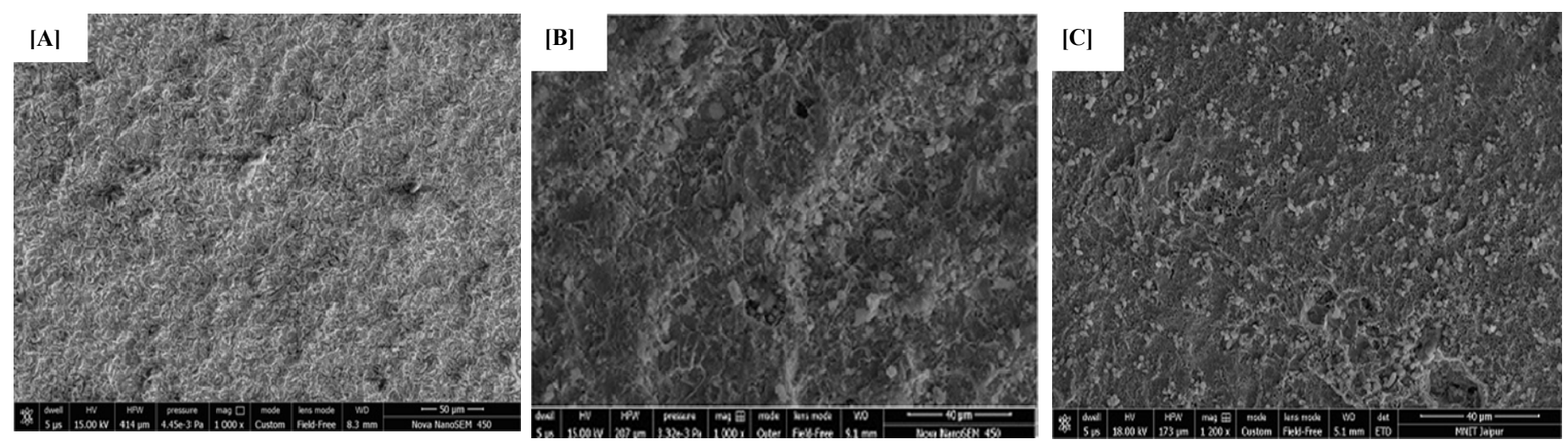

Figure 9. SEM images of mild steel with $\mathrm{HCl}$ on $40 \mu \mathrm{m}$ : [A] Polished MS; [B] MS without inhibitor; [C] MS with inhibitor (1000 ppm, 72 hr). 

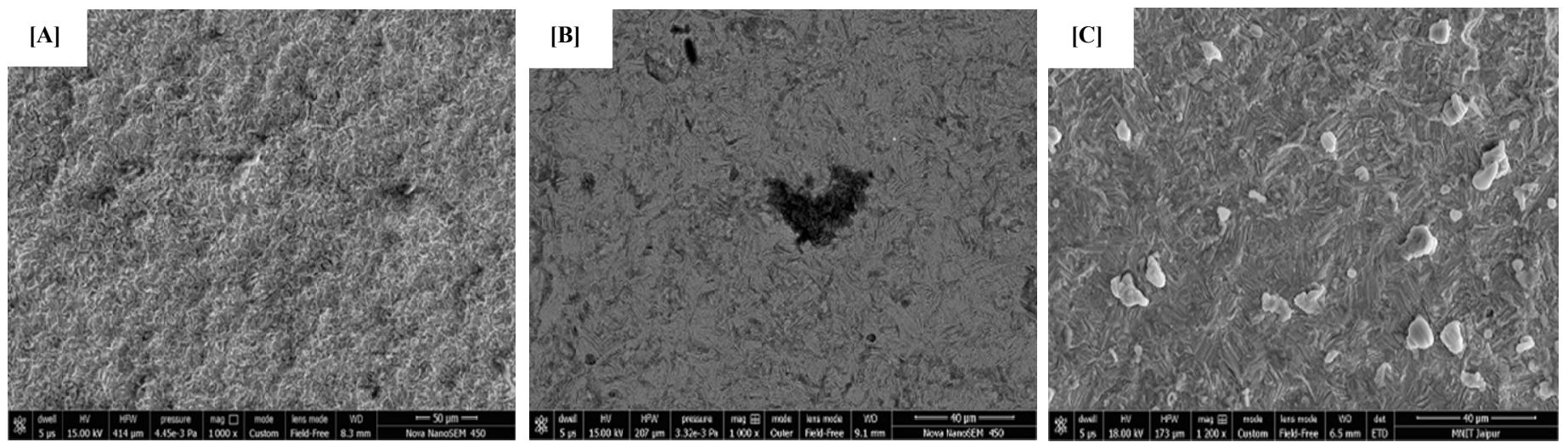

Figure 10. SEM images of mild steel with $\mathrm{H}_{2} \mathrm{SO}_{4}$ on $40 \mu \mathrm{m}$ : [A] Polished MS; [B] MS without inhibitor; [C] MS with inhibitor (1000 ppm, 72 hr).
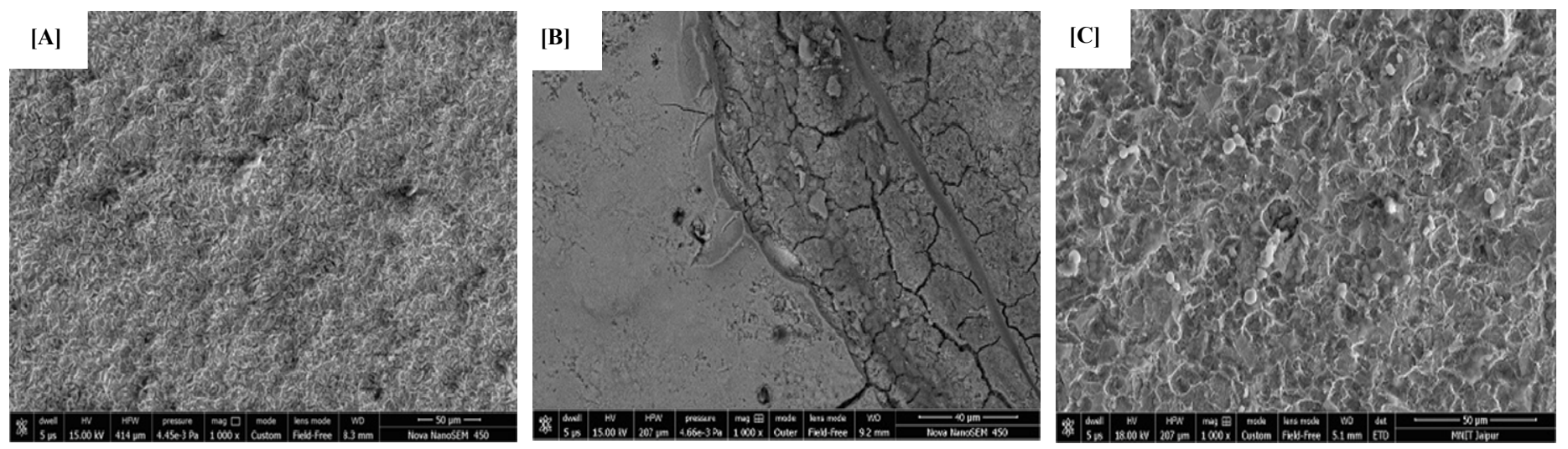

Figure 11. SEM images of mild steel with $\mathrm{HNO}_{3}$ on $40 \mu \mathrm{m}$ : [A] Polished MS; [B] MS without inhibitor; [C] MS with inhibitor (1000 ppm, 72 hr). 


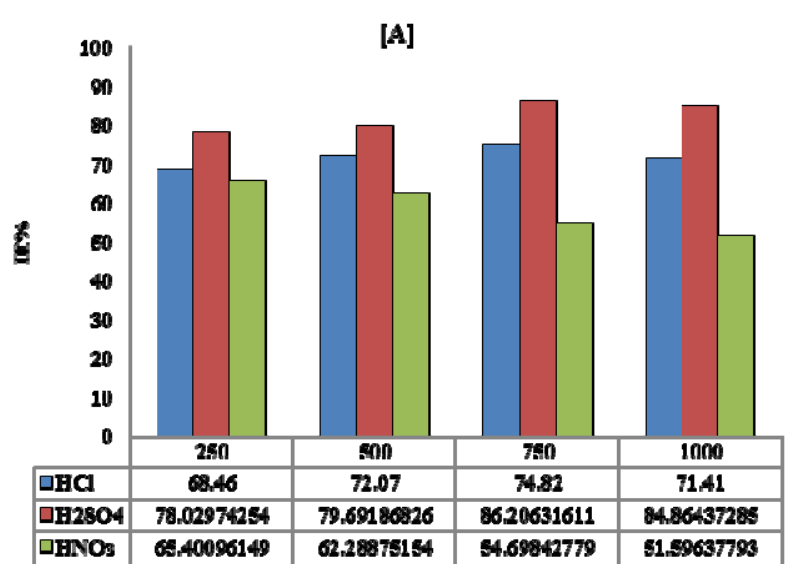

[C]

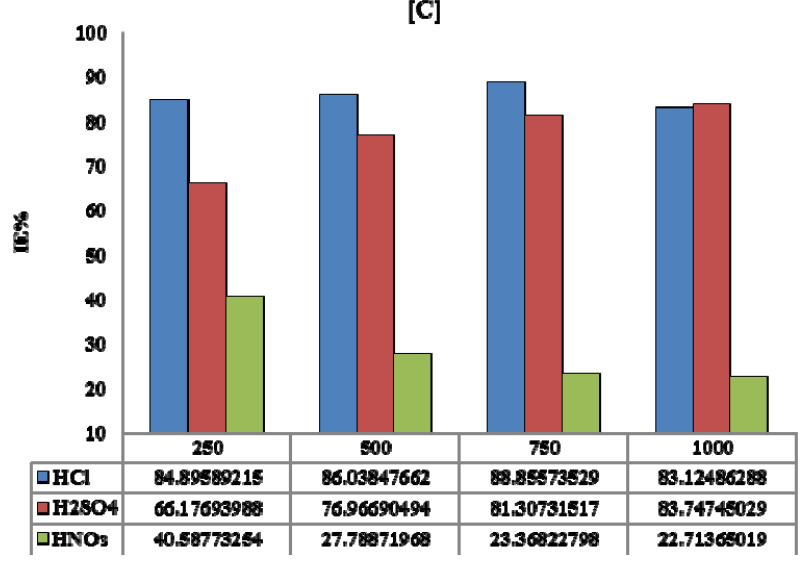

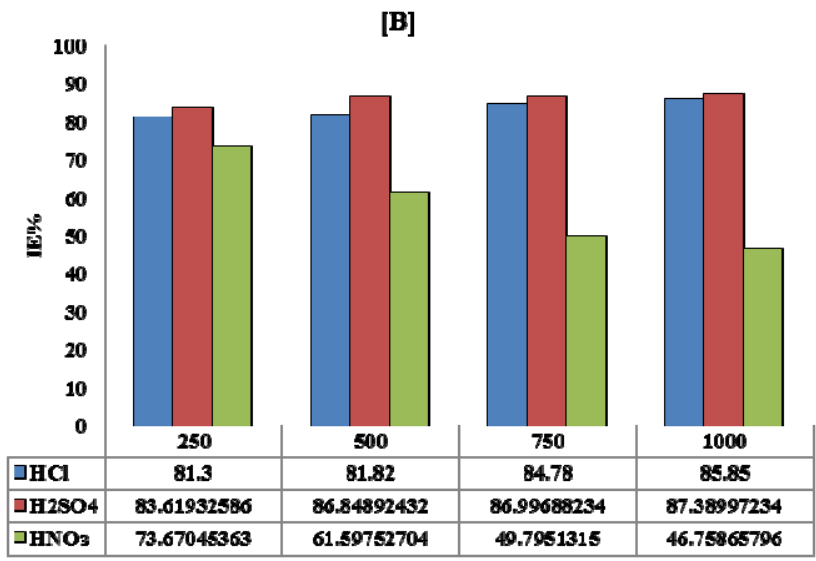

[D]

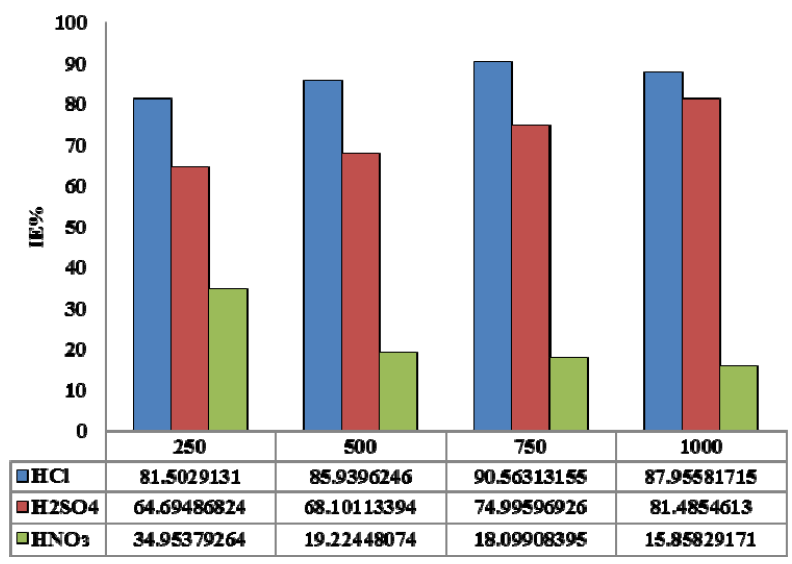

Figure 12. Comparative analysis graphs of AZI inhibitor on mild steel corrosion in $1 \mathrm{~N} \mathrm{HCl}$, $\mathrm{H}_{2} \mathrm{SO}_{4} \& \mathrm{HNO}_{3}$ at [A] $6 \mathrm{hr}$; [B] $24 \mathrm{hr}$; [C] $48 \mathrm{hr}$; [D] $72 \mathrm{hr}$.

\section{Conclusion}

- AZI testified as active and decent corrosion inhibitor for mild steel in prescribed acidic medium.

- We have found that inhibition productivity upsurge with increasing AZI inhibitor concentration in all $\left(1 \mathrm{~N} \mathrm{HCl}, \mathrm{H}_{2} \mathrm{SO}_{4} \& \mathrm{HNO}_{3}\right)$ acidic mediums, but the uppermost IE\% obtained in $\mathrm{HCl}$ medium at $1000 \mathrm{ppm}(72 \mathrm{hr})$ on $304 \mathrm{~K}$ temperature. We stated reduction in inhibition on the rise in temperature $313 \mathrm{~K}$.

- We have stated weight loss high and $\mathrm{IE} \%$ low results in the $\mathrm{HNO}_{3}$ medium as associated with $\mathrm{H}_{2} \mathrm{SO}_{4}$ and $\mathrm{HCl}$ medium due to $\mathrm{HNO}_{3}$ hyper oxidizing behave.

- Calculated activation energies and heat of adsorption supports the instances, physical adsorption which followed the Langmuir isotherm.

- According to obtained result, Azardirachta indica adsorption on metal surface was spontaneous, exothermic and supported the mechanism of physical adsorption. AZI inhibitor adsorption follows the Langmuir adsorption isotherm for MS with all three acids at $304 \mathrm{~K} \& 313 \mathrm{~K}$ temperature. 


\section{References}

1. A. Sharma, G. Choudhary, A. Sharm and S. Yadav, Effect of temperature on the inhibitory efficacy of Azadirachta indica fruit on acid corrosion of aluminum, Int. J. Innovative Res. Sci. Eng. Technol., 2013, 2, no. 12, 7982.

2. J.A. Linthorst, An overview: origins and development of green chemistry, Found. Chem., 2010, 12, no. 1, 55.

3. V. Ram, P.N. Ram, T.A.T. Khatri and P.N. Dave, Corrosion Inhibition of Aluminium in Hydrochloric Acid by Natural Plant Extracts, Research Paper (postgraduate), 2014.

4. M.E. Mashug, L.O. Olasunkanmi, A.S. Adekunle, S. Yesudass, M.M. Yesudass and E.E. Ebenso, Adsorption, thermodynamic and quantum chemical studies of 1-hexyl-3methylimidazolium based ionic liquids as corrosion inhibitors for mild steel in $\mathrm{HCl}$, Materials, 2015, 8, no. 6, 3607.

5. U.J. Ekpe, P.C. Okafor, E.E. Ebenso, O.E. Offiong and B.I. Ita, Mutual effects of thiosemicarbazone derivatives on the acidic corrosion of aluminium, Bull. Electrochem., 2001, 17, no. 3, 131.

6. P.C. Okafor, E.E. Ebenso and U.J. Ekpe, Inhibition of the acid corrosion of aluminium by some derivatives of thiosemicarbazone, Bull. Chem. Soc. Ethiopia, 2004, 18, no. 2, 181.

7. P.C. Okafor, E.E. Ebenso, U.J. Ibok, U.J. Ekpe and M.I. Ikpi, Inhibition of 4acetamidoaniline on corrosion of mild steel in $\mathrm{HCl}$ solutions, Trans. SAEST, 2003, 38, no. 3, 91 .

8. K.F. Khaled and N. Hackerman, Investigation of the inhibitive effect of orthosubstituted anilines on corrosion of iron in $0.5 \mathrm{MH}_{2} \mathrm{SO}_{4}$ solutions, Mater. Chem. Phys., 2003, 82, no. 3, 949.

9. P.C. Okafor, V.I. Osabor and E.E. Ebenso, Eco-friendly corrosion inhibitors: inhibitive action of ethanol extracts of Garcinia kola for the corrosion of mild steel in $\mathrm{H}_{2} \mathrm{SO}_{4}$ solutions, Pigm. Resin Technol., 2007, 36, no. 5, 299.

10. E.E. Ebenso and E.E. Oguzie, Corrosion inhibition of mild steel in acidic media by some organic dyes, Mater. Lett., 2005, 59, no. 17, 2163.

11. F. Zucchi and I.H. Omar, Plant extracts as corrosion inhibitors of mild steel in $\mathrm{HCl}$ solutions, Surf. Technol., 1985, 24, no. 4, 391.

12. (a.) C.O. Akalezi, C.E. Ogukwe, E.A. Ejele and E.E. Oguzie, Corrosion inhibition properties of Gongronema latifollium extract in acidic media, Int. J. Corros. Scale Inhib., 2016, 5, no. 3, 232, doi: 10.17675/2305-6894-2016-5-3-4; (b.) S.P. Ramesh, K.V. Kumar and M.G. Sethuraman, Extract of andrographis paniculata as corrosion inhibitor of mild steel in acid medium', Bull. Electrochem., 2001, 17, no. 3, 141; (c.) S. Muthumanickam, B. Jeyaprabha, R. Karthik, A. Elangovan and P. Prakash, Adsorption and corrosion inhibiting behavior of Passiflora foetida leaf extract on mild steel corrosion, Int. J. Corros. Scale Inhib., 2015, 4, no. 4, 365, doi: 10.17675/23056894-2015-4-4-6; (d.) C.O. Akalezi, C.E. Ogukwe, E.A. Ejele and E.E. Oguzie, Mild 
steel protection in acidic media using Mucuna pruriens seed extract, Int. J. Corros. Scale Inhib., 2016, 5, no. 2, 132, doi: 10.17675/2305-6894-2016-5-2-3

13. P.C. Okafor, U.J. Ekpe, E.E. E.E. Ebenso Oguzie, N.S. Umo and A.R. Etor, Extract of Allium cepa and Allium sativum as corrosion inhibitors of mild steel in $\mathrm{HCl}$ solution, Trans. SAEST, 2006, 41, no. 2, 82.

14. S.B. Ulaeto, U.J. Ekpe, M.A. Chidiebere and E.E. Oguzie, Corrosion inhibition of mild steel in hydrochloric acid by acid extracts of Eichhornia crassipes, Int. J. Mater. Chem., 2012, 2, no. 4, 158.

15. E.E. Oguzie, A.I. Onuchukwu, P.C. Okafor and E.E. Ebenso, Corrosion inhibition and adsorption behavior of Ocimum basilicum extract on aluminium, Pigm. Resin. Technol., 2006, 35, no. 2, 63.

16. P.C. Okafor and E.E. Ebenso, Inhibitive action of Carica papaya extracts on the corrosion of mild steel in acidic media and their adsorption characteristics, Pigm. Resin. Technol., 2007, 36, no. 3, 134.

17. P.C. Okafor, V.I. Osabor and E.E. Ebenso, Eco-friendly corrosion inhibitors: inhibitive action of ethanol extracts of Garcinia kola for the corrosion of mild steel in $\mathrm{H}_{2} \mathrm{SO}_{4}$ solutions, Pigm. Resin. Technol., 2007, 36, no. 5, 299.

18. E.E. Oguzie, Evaluation of the inhibitive effect of some plant extracts on the acid corrosion of mild steel', Corros. Sci., 2008, 50, no. 11, 2993.

19. P.C. Okafor, M.E. Ikpi, I.E. Uwah, E.E. Ebenso, U.J. Ekpe and S.A. Umoren, Inhibitory action of Phyllanthus amarus extracts on the corrosion of mild steel in acidic media, Corros. Sci., 2008, 50, no. 8, 2310.

20. I.E. Uwah, B.U. Ugi, P.C. Okafor and A.I. Ikeuba, Comparative study of corrosion inhibition and adsorption characteristics of ethanol extracts of Andrographis paniculata (King bitters) and Vernonia amygdalina (Bitter leaf) on Mild Steel in $\mathrm{HCl}$ solution, Int. J. Appl. Chem., 2013, 9, no. 1, 73.

21. E.E. Oguzie, C.K. Enenebeaku, C.O. Akalezi, S.C. Okoro, A.A. Ayuk and E.N. Ejike, Adsorption and corrosion-inhibiting effect of Dacryodis edulis extract on low-carbonsteel corrosion in acidic media, J. Colloid Interface Sci., 2010, 349, no. 1, 283.

22. A.J. De Britto and D.H.S. Gracelin, Azadiracta indica A Juss, A potential antimicrobial agent against Xanthomonas campestris, Int. J. Appl. Chem.Pharm. Technol., 2011, 2, no. 3, 374 .

23. M.R. Pai, L.D. Acharya and N. Udupa, Evaluation of antiplaque activity of Azadirachta indica leaf extract gel - a 6-week clinical study, $J$. Ethnopharmacol., 2004, 90, no. 1, 99.

24. A.K. Ghimeray, C.W. Jin, B.K. Ghimire and D.H. Cho, Antioxidant activity and quantitative estimation of azadirachtin and nimbin in Azadirachta Indica A. Juss grown in foothills of Nepal', African Journal of Biotechnology, 2009, 8, no. 13, 3084.

25. E.E. Oguzie, Adsorption and corrosion inhibitive properties of Azadirachta indica in acid solutions', Pigm. Resin. Technol., 2006, 35, no. 6, 334. 
26. S.K. Sharma, A. Peter and I.B. Obot, Potential of Azadirachta indica as a green corrosion inhibitor against mild steel, aluminum, and tin: a review', J. Anal. Sci. Technol., 2015, 6:26, doi: 10.1186/s40543-015-0067-0.

27. R.R. Chattopadhyay, Possible mechanism of antihyperglycemic effect of Azadirachta indica leaf extract: part V', J. Ethnopharmacol., 1999, 67, no. 3, 373.

28. M.A. Hossain and M.R. Nagooru, Biochemical profiling and total flavonoids contents of leaves crude extract of endemic medicinal plant Corydyline terminalis L. Kunth, Pharmacogn. J., 2011, 3, no. 24, 25.

29. P.S. Negi, G.K. Jayaprakasha and B.S. Jena, Distribution and introduction cultivation state of Azadirachta indica, Food Chem., 2002, 80, 293.

30. M.A. Hossain, W.A. Al-Toubi, A.M. Weli, Q.A. Al-Riyami and J.N. Al-Sabahi, Identification and characterization of chemical compounds in different crude extracts from leaves of Omani neem, J. Taibah University for Science, 2013, 7, no. 4, 181.

31. M.A. Hossain, M.D. Shah and M. Sakari, Gas chromatography-mass spectrometry analysis of various organic extracts of Merremia borneensis from Sabah', Asian Pac. J. Trop. Med., 2011, 4, no. 8, 637.

32. I.B. Obot, N.O. Obi-Egbedi and S.A. Umoren, Antifungal drugs as corrosion inhibitors for aluminium in $0.1 \mathrm{M} \mathrm{HCl}$, Corros. Sci., 2009, 51, no. 8, 1868.

33. I.B. Obot, N.O. Obi-Egbedi and N.W. Odozi, Acenaphtho [1,2-b] quinoxaline as a novel corrosion inhibitor for mild steel in $0.5 \mathrm{H}_{2} \mathrm{SO}_{4}$, Corros. Sci., 2010, 52, no. 3, 923.

34. T.J. Tuaweri, E.A. Ogbonnaya and O.O. Onyemaobi, Corrosion inhibition of heat treated mild steel with neem leave extract in a chloride medium, Int. J. Res. Eng. Technol., 2015, 4, no. 6, 2321.

35. G.L. Squadrito and W.A. Pryor, Oxidative chemistry of nitric oxide: the roles of superoxide, peroxynitrite, and carbon dioxide, Free Radical Biol. Med., 1998, 25, no. 4, 392.

36. N.O. Eddy, A.O. Odiongenyi, P.O. Ameh and E.E. Ebenso, Corrosion inhibition potential of Daniella Oliverri gum exudate for mild steel in acidic medium, Int. J. Electrochem. Sci., 2012, 7, 7425.

37. P.O. Ameh, M. Ladan and S. Takuma, Corrosion inhibition and adsorption behaviour for mild steel by Ficus glumosa gum in $\mathrm{H}_{2} \mathrm{SO}_{4}$ solution, Afr. J. Pure Appl. Chem., 2012, 6, no. 7, 100.

38. I. Dehri and M. Özcan, The effect of temperature on the corrosion of mild steel in acidic media in the presence of some sulphur-containing organic compounds, Mater. Chem. Phys., 2006, 98, no. 2, 316.

39. K.V. Kumar, V. Ramamurthi and S. Sivanesan, Modeling the mechanism involved during the sorption of methylene blue onto fly ash, J. Colloid Interface Sci., 2005, 284, no. $1,14$.

40. G.L. Squadrito and W.A. Pryor, Oxidative chemistry of nitric oxide: the roles of superoxide, peroxynitrite, and carbon dioxide, Free Radicals Biol. Med., 1998, 25, no. 4, 392. 
41. E. Osarolube, I.O. Owate and N.C. Oforka, Corrosion behaviour of mild and high carbon steels in various acidic media, Sci. Res. Essays, 2008, 3, no. 6, 224.

42. A. Peter, S.K. Sharma and I.B. Obot, Anticorrosive efficacy and adsorptive study of guar gum with mild steel in acidic medium, J. Anal. Sci. Technol., 2016, 7, no. 1, 26. 